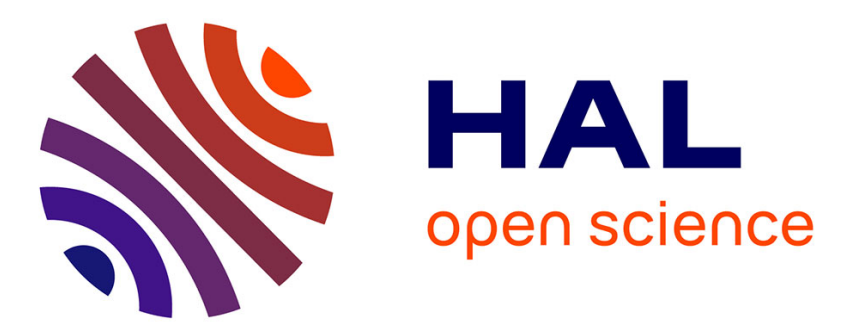

\title{
Relationships between soil fauna communities and humus forms: Response to forest dynamics and solar radiation
}

Sandrine S. Salmon, Nadia Artuso, Lorenzo Frizzera, Roberto Zampedri

\section{- To cite this version:}

Sandrine S. Salmon, Nadia Artuso, Lorenzo Frizzera, Roberto Zampedri. Relationships between soil fauna communities and humus forms: Response to forest dynamics and solar radiation. Soil Biology and Biochemistry, 2008, 40 (7), pp.1707-1715. 10.1016/j.soilbio.2008.02.007 . mnhn-02925895

\section{HAL Id: mnhn-02925895}

\section{https://hal-mnhn.archives-ouvertes.fr/mnhn-02925895}

Submitted on 31 Aug 2020

HAL is a multi-disciplinary open access archive for the deposit and dissemination of scientific research documents, whether they are published or not. The documents may come from teaching and research institutions in France or abroad, or from public or private research centers.
L'archive ouverte pluridisciplinaire HAL, est destinée au dépôt et à la diffusion de documents scientifiques de niveau recherche, publiés ou non, émanant des établissements d'enseignement et de recherche français ou étrangers, des laboratoires publics ou privés. 
Relationships between soil fauna communities and humus forms: response to forest dynamics and solar radiation

3

4 Sandrine Salmon ${ }^{\text {a,*}, \text { Nadia Artuso }}{ }^{\text {a,b }}$, Lorenzo Frizzera ${ }^{\text {c }}$, Roberto Zampedri ${ }^{\text {c }}$ 5

6 a: Muséum National d'Histoire Naturelle, Département Ecologie et Gestion de la Biodiversité, USM 301, UMR CNRS 7179, 4 Avenue du Petit Château, 91800 Brunoy, France.

8

9 b : Università di Padova, Facoltà di Agraria, Dip. TeSAF, 35020 Legnaro, Italy.

11 c: Centro di Ecologia Alpina, Gruppo Ecologia del Suolo-Humus Forestali, 38040 Viote del 12 Monte Bondone (TN), Italy.

14 *: Corresponding author:

15 Sandrine Salmon

$16 \quad$ Tel $+33(0) 160479211$

$17 \quad \mathrm{Fax}+33(0) 160465719$

18 Email: $\underline{\text { sandrine-salmon@wanadoo.fr }}$

19 Département Ecologie et Gestion de la Biodiversité, Muséum National d'Histoire Naturelle, 20 USM 301, UMR 7179, 4 Avenue du Petit Château, 91800 Brunoy, France.

24 Type of contribution: regular paper

25 Date of preparation : 2007-12-20

2628 text pages, 3 tables, 2 figures 


\section{Abstract}

This study investigated the responses of soil animal communities, soil functioning and humus forms to forest dynamics and solar radiation. We examined changes in invertebrate communities and soil features in two subalpine spruce forests (Eastern Italian Alps, Trento) growing on a calcareous bedrock, with different sun exposures (north and south), each forming a chronosequence of three developmental phases: clearing, regeneration stand (25year-old trees) and mature stand (170-year-old trees). Our results indicate that the two forest sites differed in solar energy input, soil chemical properties and the relationships between forest dynamics and animal communities. In the north-facing site, soil fauna communities were very similar in the three forest developmental phases. Conversely, in the south-facing site, the composition of invertebrate communities and the diversity of zoological groups varied greatly among developmental phases. The highest abundance of total invertebrates, and mites in particular, occurred in the south-facing mature stands while the south-facing

41 regeneration stand was characterized by higher densities of Collembola, Chilopoda, Symphyla, Protura and Aranea. The structure of communities in clearings was the same as in regeneration stands but with lower invertebrate abundance. Humus forms and soil features changed with developmental phases in both the south- and north-facing sites, although variations were more pronounced in the southern exposure. Mature stands were characterized by high levels of soil organic carbon and nitrogen, $\mathrm{C} / \mathrm{N}$ values and low $\mathrm{pH}$, the clearings and regeneration stands being characterized by a greater release of mineral nitrogen. The diversity

49 Index, the amount of organic carbon and the species richness of herbaceous plants. Our results 50 about the composition and the diversity of invertebrate communities are consistent with the 51 observations of other authors studying south-exposed forests growing on different bedrock 
types, indicating that such relationships are widespread. The higher densities of invertebrates in the south-facing site may be attributed to higher solar radiation, and the positive correlation observed between total soil fauna abundance and solar energy supports the 'more individuals' hypothesis that assumes a positive relationship between the number of individuals and energy availability. Possible ways by which forest dynamics control soil invertebrate communities are discussed.

\section{Key words}

Invertebrate communities, Humus forms, Forest dynamics, Solar energy, Spruce cycle phase.

\section{Introduction}

The richness and abundance of soil fauna, as well as the composition of invertebrate communities, may be regulated by regional factors such as climatic conditions, bedrock, altitude, forest type and succession, (Toutain, 1987; Bernier, 1996; Grossi and Brun, 1997; Materna, 2004), and by local factors such as natural disturbance dynamics, predation, canopy cover, light exposure, humus form, nutrient availability, soil $\mathrm{pH}$ and water regime (Ponge, 1993; Paquin and Coderre, 1997; Feener and Schupp, 1998; Bird et al., 2000; Loranger et al., 2001; Kuznetsova, 2002; Magura et al., 2003; Scheu et al., 2003; Cassagne et al., 2003; Salmon et al., 2005).

Vegetational changes, especially those associated with forest dynamics are assumed to greatly affect the abundance and diversity of soil invertebrates since they are correlated to most environmental and soil parameters (Miller, 1981; Bernier and Ponge, 1994; Salmon et 
availability) must particularly be taken into account to understand the relationships between soil animal communities and plant succession, because it constitutes a living substrate for both plants and soil invertebrates, (Peltier et al., 2001; Ponge, 2003). Mull and moder are two out of the three main humus forms (in order of highest to lowest levels of biodiversity) (Ponge, 2003). Mulls (comprising eumull, oligomull, amphimull and dysmull) are generally associated with early developmental stages (regeneration) of forest stands, while moders (eumoder and dysmoder) occur in phases of intense growth of trees up to maturity (Bernier and Ponge, 1994; Salmon et al., 2006).

Several studies have investigated the changes in abundance and diversity of invertebrate species, as well as changes in the species composition of communities with forest dynamics (Hågvar, 1982; Baguette and Gérard, 1993; Bernier and Ponge, 1994; Migge et al., 1998; Zaitsev et al., 2002; Chauvat et al., 2003; Grgič and Kos, 2005). However, each of these studies focused only on one animal taxon, so that only Acari, Collembola, Carabid beetles, Lumbricidae and Chilopoda were studied separately in tree stands of various ages, several other soil-dwelling invertebrates including Aranea, Diptera larvae, Symphyla, Protura and Enchytraeidae being excluded. However, different zoological taxa probably contribute differently to soil functions (Verhoef and Brussaard, 1990; Setälä et al., 1991; Vedder et al., 1996) and should be considered jointly. Moreover, investigating the diversity of a wide range of zoological groups in each successional phase, would be a better approach than studying species diversity of just one taxon, to estimate functional diversity, since some studies suggested that ecosystem process rates are more closely correlated with functional composition than with species richness (Vedder et al., 1996; Schwartz et al., 2000; Cortet et al., 2003).

A study has already evidenced the changes in soil animal communities associated with spruce (Picea abies) dynamics in a forest growing in a south-facing slope on acidic bedrock 
102 (Salmon et al., 2006); however, it is not known whether the observed relationships can be 103 generalised for different geological and climatic conditions.

On a regional scale, little is known about the response of soil animal communities to solar radiation, or to interactions between solar radiation and forest dynamics, although light is known to impact the behaviour and the local distribution of soil invertebrates (Ponge, 1993; 107 Salmon and Ponge, 1998). The 'more individuals' hypothesis (Wright, 1983; Srivastava and 108 Lawton, 1998; Gaston, 2000; Kaspari et al., 2003) assumes that there is a direct relationship 109 between energy availability, the overall resource availability in a particular area and, 110 consequently, the total number of individuals that can be maintained. A comparison of soil 111 animal communities in forests with either a southern or northern exposure, combined with 112 solar radiation measurements would allow this hypothesis to be tested in forest floor 113 ecosystem. Exposure and solar radiation could also interact with forest dynamics to affect 114 changes in soil animal communities. In fact, we may assume that changes in the composition 115 of invertebrate communities may partly result from the decrease in solar radiation (and 116 consequently temperature, Imbeck and Ott, 1987) through the canopy in mature stands.

We examined the changes in the composition of soil animal communities with sun 118 exposure and forest dynamics, and corresponding changes in humus forms, soil nutrients, and 119 soil functioning. The aims of this study were to (1) verify whether the relationships previously 120 observed between animal community composition and abundance and forest dynamics may 121 be extrapolated to other environmental (geologic and climatic) conditions and, (2) study the 122 effect of solar radiation and its interaction with spruce dynamics on soil animal communities 123 and soil functioning.

\section{Materials and methods}


128 Two natural spruce forests [Picea abies (L.) Karst.] were selected in the Eastern Italian Alps

129 (Province of Trento) at $1680 \mathrm{~m}$ above sea level, one on the south-facing slope of the Non 130 Valley and one on the north-facing slope of the Fassa Valley. The climate is continental with 131 a mean annual rainfall and temperature of $863 \mathrm{~mm}$ and $5.3{ }^{\circ} \mathrm{C}$ in the Non Valley and 1049 $132 \mathrm{~mm}$ and $4.3^{\circ} \mathrm{C}$ in the Fassa Valley, respectively. At each site, we considered three 133 developmental phases of spruce: clearing, regeneration and mature trees. The spruce stands were managed with soft silvicultural practices (selective cutting or small clear-cut area) so as to further the forest's natural regeneration.

136 The mean age of spruce in regeneration stands was 27 years (max 41, min 11) and 23 years 137 ( $\max 36, \min 17$ ) in the south and north-facing sites, respectively. In mature stands, spruce 138 were 165 -year-old $(\max 221, \min 100)$ and 180-year-old $(\max 204$, min 144$)$ in the south and 139 north-facing sites, respectively. Stands were situated on either Cambisol or Regosol (FAO, 140 1998) formed on sedimentary dolomitic rocks. The density of mature spruce was 600 and 500 141 trees/ha while regeneration density was 8000 and 15500 trees/ha, in the south- and north142 facing sites, respectively. The dominant plant species and the cover of the herbaceous layer 143 (cover greater than 35\%) are given below.

144 South-facing site (Non Valley):

145 -clearing: cover greater than 90\%; Carex montana, Calamagrostis varia, Brachypodium pin. 146 rupestre and Melica nutans.

147 - regeneration phase: two areas differing by the composition and cover of the herbaceous 148 layer, (1) cover greater than 90\% (six samples); Carex montana, Viola biflora and 149 Brachypodium pin. rupestre, (2) mean cover of 35\% (two samples); Vaccinium vitis-idaea 150 and Vaccinium myrtillus. 
151 - mature phase: two areas, (1) cover varying from 0 to $35 \%$ (six samples); Vaccinium vitis152 idaea and Vaccinium myrtillus, (2) cover greater than 90\% (two samples); Carex montana, 153 Calamagrostis varia, Brachypodium pin. rupestre and Melica nutans.

$154 \quad$ North-facing site (Fassa Valley):

155 - clearing: two areas, (1) cover of 75\%; Sesleria albicans, Deschampsia flexuosa, Carex alba, 156 Melampyrum sylvaticum, Oxalis acetosella and Viola biflora, (2) cover of 15\% (for one 157 sample); Oxalis acetosella and Viola biflora.

158 -regeneration phase: two areas, (1) cover of 15\% (five samples); Oxalis acetosella and Viola 159 biflora, (2). cover of 75\% (three samples); Adenostyles alpina, Carex montana, Viola biflora, 160 Chaerophyllum hirsutum, Sesleria albicans and Deschampsia flexuosa.

161 - mature phase: two areas, (1) cover of 20\% (four samples); Hieracium muroru, Clematis 162 alpina,Luzula nivea and Rubus saxatilis, (2) cover of 75\% (four samples); Melampyrum 163 sylvaticum, Sesleria albicans and Carex alba. Eight sampling points, distant from three to nine meters from each other, were randomly selected in each developmental phase for each exposure. The main south-facing sampling plot covers an area of $1800 \mathrm{~m}^{2}$ with a mean slope of $15 \%$. As we could collect only four samples in the mature stand, we chose four sampling points of 'mature trees' in a small area $\left(200 \mathrm{~m}^{2}\right)$ situated $50 \mathrm{~m}$ from the main plot to complete the sampling regime. The northfacing sampling plot covers a surface of $1000 \mathrm{~m}^{2}$ with a mean slope of $16 \%$. sampled using polystyrene boxes (4.2 $1 \times 8.4 \mathrm{~L} \times 11.3 \mathrm{~cm}$ depth) and used for soil analysis 173 in plastic bags and used to extract enchytraeids (see below). 
176 Enchytraeids were extracted two days after soil sampling by the modified wet-funnel method 177 of O'Connor (1957). After 6, 12 and 24 hours, enchytraeids were collected in Petri dishes and 178 immediately counted under a magnifying glass. Arthropods were extracted from the soil cores 179 stored in plastic boxes after a set of respiration measurements and leachate analysis was 180 completed (see below), i.e. 25 days after sampling. During this period soil cores were 181 rehydrated by the addition of $40 \mathrm{ml}$ of deionised water once a week. Animals were extracted by the dry funnel method (Edwards and Fletcher, 1971) and fixed in 90\% ethyl alcohol. Each sample was placed in a flat glass cup, the bottom of which was divided into 200 compartments, and observed under a binocular magnifying glass (40X). Whole macrofauna was counted and identified while microarthropods were counted in 50 randomly-selected compartments out of 200 (Salmon et al, 2006). Animals were identified at the level of group, order, super-family or family (Dindal, 1990; Dunger and Fiedler, 1997).

\subsection{Environmental factors}

We measured ten environmental factors believed to be relevant in controlling the distribution of soil fauna. Total annual solar radiation received at the soil surface was indirectly measured with the hemispherical canopy photography technique (Neumann et al., 1989): an image is captured at an angle of $180^{\circ}$ on the perpendicular plane and $360^{\circ}$ on the parallel plane to a fisheye lens mounted on a digital camera. A 10x10m grid was placed in each sampling plot and a hemispherical canopy photograph was taken at each grid intersection. Direct radiation $\left(\mathrm{MJ} . \mathrm{m}^{-2} . \mathrm{d}^{-1}\right)$ was calculated using the software Gap Light Analyzer version 2.0 (Frazer et al., 1999). This software also estimates canopy structural parameters using site characteristics such as latitude, slope, sun exposure and altitude. Results were interpolated with ordinary

199 kriging, generating a radiation map of each entire plot, including the sampling points of the 200 soil fauna. 
201 At each sampling point, humus forms (Table 1) were identified using the morphological 202 criteria defined by Brêthes et al. (1995) and Baize et al. (1995), and a Humus Index was 203 attributed to each form (Ponge et al., 2002). Soil nutrients were analysed in leachates released 204 from soil cores contained in the plastic boxes, after adding deionized water to collect $40 \mathrm{ml}$ 205 leachates. Percolating water was collected for 12 hours after the irrigation through a tube 206 attached to the underside of the box. Ammonium-N and nitrate- $\mathrm{N}$ contents in leachates were 207 measured colorimetrically by continuous flow analysis (Krom, 1980). The concentration of 208 soluble organic carbon in leachates was calculated with an infrared C analyzer after burning $20940 \mu \mathrm{l}$ subsamples at $+950^{\circ} \mathrm{C}$ (INRA Laboratory of Soil Analysis, Arras, France). To assess 210 soil functioning at each sampling point, carbon mineralised as $\mathrm{CO}_{2}\left(\mathrm{CO}_{2}-\mathrm{C}\right)$ released by soil 211 cores was measured. $\mathrm{CO}_{2}$ release was determined with an infra-red gas analyser (Polytron IR $212 \mathrm{CO}_{2}$ DIMARSOL, Dräger®) after incubation of soil cores in air-tight containers for $4 \mathrm{~h}$ at $21315^{\circ} \mathrm{C}$.

Organic carbon and total nitrogen contents in soil were estimated from $50 \mathrm{mg}$ of dried 215 soil from each soil core after arthropod extraction. The soil samples were grounded to $100 \mu \mathrm{m}$ 216 and homogenised before measurements with a $\mathrm{CHN}$ atomic analyser (Perkin Elmer CHNS/O 217 Analyzer 2400 Series II.). Soil $\mathrm{pH}-\mathrm{H}_{2} \mathrm{O}$ was determined using soil mixed with deionised 218 water (soil:water 1:5 v/v) for $5 \mathrm{~min}$; $\mathrm{pH}$ was measured $4 \mathrm{~h}$ after mixing (Anonymous, 1999).

\subsection{Statistical analyses}

221 Data were first analyzed by Correspondence Analysis (CA) using StaboxPro 5 software $222\left(\right.$ Grimmersoft $\left.^{\circledR}\right)$ in order to compare invertebrate communities in the different stands and exposures. CA allows representing active variables, namely abundance of taxa, and samples simultaneously by projecting points on a plane formed by the two first factorial axes. Physical and chemical soil parameters ( $\mathrm{pH}$, soil organic carbon, soil nitrogen, $\mathrm{C} / \mathrm{N}$ ratio, humus index), 
leachate nutrients (mineral nitrogen, nitrates, ammonium, soluble organic carbon), direct solar radiation, animal community characteristics (predator abundance, total abundance, taxonomic richness), sun exposure (north or south) and the developmental phase of trees (clearing, regeneration or mature trees) acted as passive variables to explain the distribution of active 230 variables, without affecting and constraining their ordination. Predator taxa include 231 centipedes, cantharids, staphylinids, gamasid mites and spiders (Scheu and Falca, 2000). All variables were standardized prior to analysis, and each variable was associated with a conjugate, varying in an opposite sense in such a way that each animal group is represented by two points, one indicating higher densities for this group, the other lower densities (see Salmon et al., 2006 for data transformations). Rank correlations between variables and factorial axes were calculated using Spearman's method.

Correlations between total animal abundance and direct solar radiation, and between the diversity of zoological groups (Shannon-Wiener index) and the cover and species richness of herbaceous plants, were calculated for both north- and south-facing sites pooled together, using simple linear regressions (Sokal and Rohlf, 1995; XLSTAT 2006.5 ${ }^{\circledR}$ software). A 241 multiple linear regression was performed between Shannon-Wiener index and soil $\mathrm{pH}$, 242 Humus Index, and soil carbon and nitrogen content (relationships revealed by CA).

As data set and transformed data set did not meet homosedasticity requirements, we could not perform two-way ANOVA to test differences in the total abundance, zoological richness (number of zoological groups, i.e. names in bold type in Table 1), zoological 246 diversity (Shannon-Wiener index based on zoological groups), solar radiation and soil 247 characteristics in each growth phase of trees. Differences were thus tested by the Kruskal248 Wallis test, together in north-facing and south-facing sites. When the difference was 249 significant, the six means were compared two by two and the significance level of this multiple comparison was corrected according to Bonferoni (Dunn, 1964; XLSTAT 2006.5 ${ }^{\circledR}$ 
251 software). Coordinates of axis 1 and 2, (that express the community composition) in each 252 developmental phase and each exposure were compared by a Kruskal-Wallis test and a Mann253 Whitney test respectively. At last, a one-way ANOVA with two replicates, (the south and 254 north-facing sites being considered as two replicates) was performed in order to assess 255 whether the variations in total abundance, zoological richness and diversity, respectively, 256 between the developmental phases of spruce occur in the same way in different sites.

\section{Results}

The results of the first CA showed that one sampling point in the mature stand of the southfacing site (MS7) was an outlier; therefore, we performed CA without MS7 (Figs. 1 and 2).

261 Axis 1 of the CA (representing $20 \%$ of the total variance in zoological taxa) depicts a gradient 262 of increasing abundance of most zoological taxa (Fig. 1). The projection of developmental 263 phase, exposure, and zoological variables on this axis indicates that the abundance of most 264 taxa and total fauna, as well as zoological richness increased from the north- to the south265 facing site and from clearings and mature stands to the south-facing regeneration stand (Fig. 266 1). Increased animal abundance in the south-facing site was mainly due to the high numbers 267 of mites (especially Oribatida, $56 \%$ of total abundance) in mature and regeneration stands, 268 and Collembola (especially Entomobryomorpha and Poduromorpha; 23\% of total abundance) 269 in the clearing and regeneration stand (Table 1). A similar pattern was observed for other 270 groups such as Coleoptera and mite larvae, uropods, gamasids, and predators, which were 271 more abundant in the south- than in the north-facing site, whereas the number of Symphyla, 272 Chilopoda, Coleoptera (including Staphylinidae), Protura, Aranea and Actinedida was more 273 increased in the south-facing regeneration than in the south-facing clearing and the three 274 north-facing developmental phases of spruce (Fig. 1, Table 1). 
Axis 2 of CA displays a clear separation between the structure of invertebrate communities in clearing and regeneration stands and that in mature stands (Fig. 1). The abundance and occurrence of several taxa (Chilopoda, Symphyla, Aranea, Protura, Coleoptera, and to a lesser extent, Collembola,) was higher in clearing and regeneration phases than in the mature phase (Fig. 1). In fact, for both the north- and south-facing sites, these open forest phases do not display profound differences in animal communities, and form a homogeneous group, characterized by the highest fauna diversity (Shannon -Weaver index) on the negative side of axis 2 . Axis 2 also shows a gradient of fauna abundance with higher total animal density in mature stands due to the high density of Acari (especially Oribatida, Gamasida and mite larvae).

Both, axis 1 and 2 of CA show that the composition of communities was more similar to each other in the three north-facing stands than in different stands in the south-facing site (Fig. 1). The pattern of Shannon-Wiener index in the north-facing site paralleled nevertheless that in the south-facing site, with a lower zoological diversity in mature stands (Fig. 1, Table

2). Considering the two sites as replicates, ANOVA indicated that Shannon index was as high in regeneration stands as in clearings, and the lowest in the mature stands $(p=0.016)$; the variations of zoological richness between developmental phases were not significant ( $\mathrm{p}>0.05)$, and total abundance was higher in mature stands than in the two other stands, which did not differ significantly from each other.

The significant difference of the axis 2 coordinates among the three developmental 297 from those in clearings and regeneration stands. Coordinates of axis 1 were marginally 298 significant $(\mathrm{p}=0.08)$ although the a posteriori Bonferroni test (significant at $\mathrm{p}=0.003$ ) 299 indicated that the structure of communities in the south-facing regeneration differed at least 
partly from that of the south-facing clearing and the three north-facing developmental phases of spruce (Table 2).

Direct solar radiation was positively correlated to axis 1 , and as expected, was the highest in the southern exposure (Figs. 1 and 2, Table 1), but no difference was observed among developmental phases of spruce. The linear regression between direct radiation and total animal abundance was marginally significant $\left(\mathrm{p}=0.059, \mathrm{R}^{2}=0.077\right)$, and animal abundances were distributed into two clusters according to exposure. Two linear regressions were thus performed separately in each exposure. In the north-facing site, no correlation was observed between solar radiation and the abundance of invertebrates $\left(\mathrm{R}^{2}=0.000, \mathrm{p}=0.963\right)$, whereas both variables were significantly correlated in the southern exposure $\left(R^{2}=0.259, p=\right.$ $0.013)$.

Humus forms in the both north- and south-facing clearings consisted in Eumull and Amphimull. In regeneration stands humus forms were more heterogeneous, varying from 313 Eumull to Dysmull, including Oligomull, in the south-facing site, and from Eumull to 314 Amphimull in the north-facing site. At last, in mature stands Dysmoder and Amphimull were 315 observed in the south-facing stand, while only Amphimull occurred in the north-facing stand. 316 The soil of mature stands were characterized by high Humus Indices and low pH values, high 317 soluble and soil organic carbon and increased $\mathrm{C} / \mathrm{N}$ ratio, as indicated by the axis 2 of CA (Fig. 318 3, Table 1). These physical and chemical properties reflect the presence of a thick litter layer 319 accompanied by a slow decomposition of organic matter. In contrast, the soil in clearings and 320 regeneration stands was characterized by a low Humus Index, and high $\mathrm{pH}$ level. High 321 mineral nitrogen content, especially nitrates, in leachates, was particularly observed in the 322 south-facing regeneration stand (Fig. 2, Table 1). These parameters indicate an increased 323 decomposition in the clearing and regeneration stands, especially in the south-facing site. 324 However, although the higher rate of soil organic matter decomposition was associated to 
clearings and regeneration stands (Fig. 2), it was not correlated to axis 2 because its pattern varied among the south- and north- facing sites (Table 2), soil respiration being unexpectedly low in the north-facing regeneration stand.

Most mineral nitrogen in leachates was in the form of nitrates (Table 1). Nitrates and consequently total mineral nitrogen in the south-facing site exceeded those in the north-facing site (Table 1). This was also true for soil organic carbon and nitrogen contents (Table 1) 331 although it is not depicted by CA because these variations does not concern regeneration stands (Fig. 2). Seven soil parameters out of ten varied among the developmental phases in the north-facing (soluble organic carbon, mineral nitrogen and nitrates in leachates, soil organic carbon, $\mathrm{C} / \mathrm{N}$ ratio, Humus index, $\mathrm{CO}_{2}-\mathrm{C} /$ soil organic carbon) (Table 1). These variations paralleled those in the south-facing site except for $\mathrm{CO}_{2}-\mathrm{C} /$ soil organic carbon (see above). The relationship between soil $\mathrm{pH}$, soil carbon and nitrogen content, Humus Index and Shannon-Wiener index revealed by CA (Figs. 1 and 2), was confirmed by the multiple linear regression (adjusted $\mathrm{R}^{2}=0.372, \mathrm{p}<0.0001$ ), but the best model that explains the values of

339 Shannon-Wiener index was obtained using $\mathrm{pH}$, carbon and Humus Index without nitrogen as 340 explicative variables (adjusted $\mathrm{R}^{2}=0.383, \mathrm{p}<0.0001$ ) in both south and north-facing sites. A 341 significant linear regression was observed between Shannon-Wiener index and the species 342 richness of herbaceous plants $\left(\mathrm{p}=0.038, \mathrm{R}^{2}=0.072\right)$, but the relationship with herbaceous 343 cover was not significant.

\section{Discussion}

\subsection{Forest dynamics and soil characteristics}

348 In the south-facing site, humus form, physical and chemical parameters and composition of 349 invertebrate communities were correlated with the developmental phase of spruce, confirming 
the pattern observed in three previous studies that were conducted in spruce stands growing on different types of bedrock (Bernier and Ponge, 1994; Salmon et al., 2006 submitted). Indeed, these studies showed that mull is associated with early developmental stages (regeneration) of forest stands, while moder is more common for phases of intense growth up to maturity. In our study, the increase of Humus Index from clearing to mature stands support this pattern, but the presence of amphimull, an intermediate form between moder and mull, characterized by an accumulation layer of small fecal pellets ( $\mathrm{OH}$ horizon), in the clearings and mature stands of both the south- and north-facing sites, indicates that these forest stands are still in evolution. The unexpected and exclusive presence of amphimull in the north-facing mature stand instead of moder (dysmoder) was probably also due to the relatively low density of mature trees in this stand.

361 Dysmoder and amphimull found in mature stands at both the north- and south-facing sites were characterized by a lower decomposition rate, indicated by (1) higher organic carbon and total nitrogen content; (2) greater quantities of soluble organic carbon; (3) lower levels of mineral nitrogen, especially nitrates; and (4) lower $\mathrm{pH}(\mathrm{pH} 4.4)$ than clearing and regeneration stands. The mineralizing activity (respiration) was also the lowest in the south-facing mature stand. These results confirm previous reports in the literature (Berg et al., 1982; Ponge, 2000) indicating a lower biological transformation efficiency of organic matter under mature trees. The decrease in mineralization and decomposition rate with stand age is in line with the decrease in metabolic activity, microbial activity and bacteria number observed by Chauvat et al. (2003) from 5-25 to 45-95 year-old spruce stands, while the fungal biomass increased.

371 Several studies suggest that the accumulation of polyphenols (in spruce needles) and antibiotic organic matter (in fungal hyphae) slow down microbial mineralization in mature stands (Gallet, 1992; Bending, 2003). In this context, the low mineralization activity (ratio $\mathrm{CO} 2-\mathrm{C} /$ soil organic carbon) in the north-facing regeneration is unexpected, even though 
values of Humus Index indicate that humus form in the north-facing regeneration is more similar to that in mature stand than that in clearing (as it is the case in the southern exposure). solar energy through temperature (Imbeck and Ott, 1987) to impact microbial activity (Parmelee, 1995), and consequently regulate decomposition rate according to the area of canopy, was not supported by our results since solar radiation levels were similar in the three developmental phases.

\subsection{Forest dynamics and animal communities}

384 The thick holorganic layers of moder soil are a good habitat for some soil invertebrates, 385 especially mites (Ponge, 1985; Hågvar and Kjøndal, 1981; Hasegawa and Takeda, 1996). This 386 is supported by the high number of mites observed in mature stands. In our study, the 387 distribution of mites, particularly oribatids is in contrast with that recorded in a spruce 388 plantation by Zaitsev et al. (2002), who observed the highest oribatid density in the 25 389 (compared to 5, 45 and 95) year-old tree stand while Migge et al. (1998) found no differences 390 in oribatids between developmental phases. The discrepancies in mites density between the 391 different studies probably result from variations in the evolution of soil characteristics associated with spruce dynamics, depending on altitude (Bernier, 1996) and forest management, since the thickness of organic layers and soil $\mathrm{pH}$ shown here do not parallel 394 those in spruce plantations in Germany (Zaitsev et al., 2002).

The abundance of Collembola was higher in the clearings and regeneration stands 396 (mean $\mathrm{pH}$ 6.5) than in the mature stands ( $\mathrm{pH} 4.4$ ), especially in the south-facing site. Many studies have demonstrated that contrary to our observations, Collembola populations do not change with the age of spruce (Chauvat et al., 2003; Scheu et al., 2003), or increase with the 
400 the influence of spruce dynamics on the variation of Collembola density probably varies with 401 forest management, and may depend on factors other than soil $\mathrm{pH}$ such as tree physiology. 402 The dense root system of spruce, which may induce a decrease in water and nutrient 403 availability (Babel, 1977; Miller, 1981), and the lower species richness and cover of herb 404 layer (especially in the south-facing site), more palatable than the recalcitrant spruce litter 405 (Edwards, 1974; Ponge, 1991; Gallet, 1992), may be responsible for the lower abundance of 406 Collembola (Christiansen, 1964) in mature stands. Variation in the densities of Collembola 407 among developmental phases of spruce depended on their superfamily, which confirms the 408 relationship between the spatial distribution of collembolan species (particularly 409 entomobryids) and tree stand type reported by Huhta and Mikkonen (1982), and the influence 410 of soil $\mathrm{pH}$ on the species composition of collembolan communities (Chagnon et al., 2000). Chilopoda and Aranea were more numerous in regeneration stands than under clearing 412 and mature trees, which corroborates previous observations in beech and spruce forests (Grgič 413 and Kos, 2005; Salmon et al., 2006, submitted) and mull versus moder humus forms 414 associated to developmental phases of trees (Athias-Binche, 1982; David et al., 1993). Their 415 distribution may be explained by the presence of litter (habitat) and the greater number of 416 potential prey, especially Collembola, in the regeneration stand (Lawrence and Wise, 2000). 417 The distribution of Symphyla, which occurred at higher density in the clearings and 418 regeneration stands, probably depends on higher $\mathrm{pH}$ values (Edwards, 1958).

419 The composition of invertebrate communities in clearings was similar to that of 420 regeneration stands, but both stands differed by the abundance of most taxa, particularly in the 421 south-facing site, which confirms results of other studies (Addison et al., 2003; Grgič and 422 Kos, 2005). The absence of spruce litter and holorganic layers, that are the habitat of a 423 number of arthropods, probably results in such a variation of abundance. 

in regeneration stands and clearings (mull and amphimull) than in mature stands (dysmoder and amphimull) in both the north- and south-facing sites. This pattern results from the increased abundance of Collembola, Protura, Symphyla and Aranea in open habitats 428 (including regeneration) and reflects a higher functional diversity, compared to closed 429 habitats. This result corroborates the observation of Salmon et al. (2006, submitted) and the assumption of Schaefer and Schauermann (1990) that higher zoological diversities are related 431 to mull humus forms in forests. Paquin and Codere (1997) also observed a decline in 432 macroarthorpod diversity with forest succession but the three studied successional phases 433 were composed of varied tree species. This relationship between invertebrate diversity and 434 developmental phases of trees is partly explained by the decrease in the diversity (perhaps 435 through the quality) of herbaceous plant and soil $\mathrm{pH}$, and the increase in soil organic carbon 436 and Humus Index, induced by actively growing and mature tree, as indicated by the correlations between Shannon-Wiener index and the four variables. The accumulation of 438 litter, resulting from the increase of spruce needle input beneath mature stands, is 439 accompanied by a decrease of soil $\mathrm{pH}$ that affects the distribution of soil animals (Salmon and 440 Ponge, 1999; Schaeffer and Schauerman, 1990).

The composition of soil fauna communities and their abundance were relatively 442 homogeneous among the three developmental phases of spruce in the north-facing compared 443 to the south-facing site; the pattern of humus forms and chemical parameters in the north444 facing site does not parallel that of invertebrate communities since seven parameters indicated 445 higher decomposition rate in the regeneration and clearing than in mature stands. The greater 446 homogeneity among soil animal communities of different developmental phases in the north447 facing site confirms that observed on a slightly more acidic bedrock (Salmon et al., 448 submitted). In the same way, changes in animal diversity and composition of communities 
449 with the developmental stage of spruce that we observed here, in a forest growing on a 450 calcareous substrate, paralleled those previously observed in a south-facing slope on acidic 451 and sub-acidic parent-rocks (Salmon et al., 2006, submitted), particularly those results for 452 regeneration stand, which had the highest soil animal diversity and the highest abundance of 453 Collembola and Chilopoda. This variation between southern and northern exposures can't be 454 explained by a higher decrease of solar radiation through the canopy of mature trees (affecting 455 microclimatic conditions; Imbeck and Ott, 1987) in the south-facing site, since solar 456 radiations were not significantly different in the three stands, in the both southern and northern exposures.

\subsection{Influence of exposure and solar radiation}

460 Total animal abundance was higher in the south- compared to the north-facing site, especially 461 in regeneration stands. The two sites received different quantities of solar energy, with low 462 inputs at the north-facing site and higher inputs at the south-facing site. The positive 463 correlation between the total abundance of soil fauna and solar energy support the "more 464 individuals" hypothesis (Wright, 1983; Srivastava and Lawton, 1998; Gaston, 2000; Kaspari 465 et al., 2003) which predicts a relationship between energy availability and the total number of 466 live individuals. We may assume that the higher energy input in the south-facing site results 467 in an increase in soil temperature (Imbeck and Ott, 1987), which creates better conditions for 468 the survival and development of microbial communities, and therefore, of soil arthropods 469 (Parmelee, 1995). Squartini (unpublished observations, 2006), carried out a similar study on 470 the same sites, and found a higher bacteria biomass in the south-facing site, which 471 corroborates our assumption. 
474 Our results show that changes in soil animal diversity and community composition, as well as 475 physical and chemical soil characteristics, and humus forms with the developmental phase of 476 trees may be generalised to all south-facing alpine spruce forests, growing on diverse 477 geological substrates. The common pattern consists of the increase of invertebrate abundance, 478 and a decrease in the zoological diversity and decomposition rate with the age of trees.

Although our study failed to demonstrate the impact of the interaction between forest dynamics and exposure in the assemblage and diversity of soil invertebrates, (especially in the southern exposure where solar radiation was similar in the three growth phases), it contributed to show the considerable impact of exposure on below-ground systems, affecting both the abundance of soil fauna and the relationships between the composition of communities and 484 forest dynamics. Conversely, the pattern of zoological diversity did not vary with exposure. 485 This means that in both southern and northern exposures, the structure of communities changes with spruce dynamics, with a decrease in the number of dominant zoological groups in mature stands (Shannon-Wiener index), but the taxa that compose invertebrate communities varied only between the growth phases of spruce in the southern exposure, particularly between mature and regeneration stands.

Our results are consistent with the hypothesis that forest dynamics, through tree 491 physiology, drive the soil functioning (including the composition and biodiversity of soil 492 invertebrate communities) during the build-up phase of succession (between regeneration and 493 mature trees) and is ultimately determined by the functional traits of the dominant species 494 present (Wardle, 2002), namely spruce. In fact, changes in invertebrate communities and 495 humus forms with successional stage may be explained by (1) a decrease in the quality of food resource for most invertebrates except Acari, with the decrease of the diversity and 497 abundance of herbaceous plants and their replacement by spruce needles in mature stands, 498 especially in the southern exposure where changes in the composition of invertebrate 
communities between the developmental phases were the most pronounced, (2) the increasing 500 input of spruce needles (habitat) expressed by higher Humus Index, $\mathrm{C} / \mathrm{N}$ ratio, and the greater 501 amount of organic carbon, accompanied by an increase of soil acidity, and (3) an 502 impoverishment of soil nutrients expressed by the decrease in mineral nitrogen.

\section{Acknowledgements}

This study was funded by the Autonomous Province of Trento and the Centro di Ecologia Alpina of Trento (Italy) as part of the Dinamus (Forest dynamics and humus) project.

508 The authors are grateful to Gerard Bellier from IRD (Institut de Recherche pour le 509 Développement, in Bondy, France) for his collaboration for soil respiration measurements.

510 They thank Jean-François Ponge and Céryl Techer from the Muséum National d'Histoire 511 Naturelle, Paris for fruitful discussions and the making of soil sampling boxes, respectively. 512 The authors thank Silvia Chersich from the Centro di Ecologia Alpina for geological 513 clarifications, Gianluca Soncin for providing the history of our study sites, and Mirco Tomasi 514 and Matteo Girardi for conducting the carbon and nitrogen analyses.

\section{References}

517 Addison, J.A., Trofymow, J.A., Marshall, V.G., 2003. Abundance, species diversity, and community structure of Collembola in successional coastal temperate forests on

520 Anonymous, 1999. Qualité des sols, vol 2. AFNOR (Paris), Paris.

521 Athias-Binche, F., 1982. Ecologie des Uropodes édaphiques(arachnides: parasitiformes)de trois écosystèmes forestiers. 3. Abondances et biomasses des microarthropodes du sol; 
facteurs du milieu, abondances et distributions spatiales des Uropodides. Vie et Milieu $32,47-60$.

Babel, U., 1977. Influence of high densities of fine roots of Norway spruce on processes in humus covers. Ecological Bulletin (Stockholm) 25, 584-586.

Baguette, M., Gérard, S., 1993. Effects of spruce plantations on carabid beetles in southern Belgium. Pedobiologia 37, 129-140.

Baize, D., Girard, M.C., 1995. Référentiel Pédologique. INRA Éditions, Paris, 332 pp.

Bending, G.D., 2003. Litter decomposition, ectomicorrhizal roots and "Gadgil" effect. New Phytologist 158, 228-229.

Berg, B., Hannus, K., Popoff, T., Theander, O., 1982. Changes in organic chemical components of needle litter during decomposition. Long-term decomposition in a Scots pine forest. I. Canadian Journal of Botany 60, 1310-1319.

Bernier, N., 1996. Altitudinal changes in humus form dynamics in a spruce forest at the montane level. Plant and Soil 178, 1-28.

Bernier, N., Ponge, J.-F., 1994. Humus form dynamics during the sylvogenetic cycle in a mountain spruce forest. Soil Biology and Biochemistry 26, 183-220.

Bird, S., Coulson, R.N., Crossley, D.A., Jr., 2000. Impacts of silvicultural practices on soil and litter arthropod diversity in a Texas pine plantation. Forest Ecology and Management 131, 65-80.

Brêthes, A., Brun, J.-J., Jabiol, B., Ponge, J.-F., Toutain, F., 1995. Classification of forest humus forms: a French proposal. Annales des Sciences Forestières 52, 535-546.

Cassagne, N., Gers, C., Gauquelin, T., 2003. Relationships between Collembola, soil chemistry and humus types in forest stands (France). Biology and Fertility of Soils 37, 355-361. 
Chagnon, M., Pare, D., Hebert, C., 2000. Relationships between soil chemistry, microbial biomass and the collembolan fauna of southern Quebec sugar maple stands. Ecoscience 7, 307-316.

Chauvat, M., Zaitsev, A.S., Wolters, V., 2003. Successional changes of Collembola and soil microbiota during forest rotation. Oecologia 137, 269-276.

Christiansen, K., 1964. Bionomics of Collembola. Annual Reviews of Entomology 9, 147178.

Cortet, J., Joffre, R., Elmholt, S., Krogh, P.H., 2003. Increasing species and trophic diversity of mesofauna affects fungal biomass, mesofauna community structure and organic matter decomposition process. Biology and Fertility of Soils 37, 302-312.

David, J.F., Ponge, J.-F., Delecour, F., 1993. The saprophagous macrofauna of different types of humus in beech forests of the Ardenne (Belgium). Pedobiologia 37, 49-56.

Dindal, D. L., 1990. Soil Biology Guide. New-York, Wiley.

Dunger, W., Fiedler, H. J., 1997. Methoden der Bodenbiologie. Jena, Gustav Fischer Verlag.

Edwards, C.A., 1958. The ecology of Symphyla: part I. populations. Entomologia Experimentalis et Applicata 1, 308-319.

Edwards, C.A. 1974. Macroarthropods. In: Dickinson, C.H., Pugh, D.J.F. (eds.), Biology of plant litter decomposition. Vol 2. Academic Press, London, London, pp. 533-554.

Edwards, C.A., Fletcher, K.E. 1971. A comparison of extraction methods for terrestrial arthropods. In: Phillipson, J. (ed.) Methods of Study in Quantitative Soil Ecology: Population, Production and Energy Flow. Blackwell, Oxford, pp. 150-185.

FAO, 1998. World reference base for soil resources. (FAO 84). FAO, Rome.

Feener, D.H., Jr., Schupp, E.W., 1998. Effects of treefall gaps on pathchiness and species richness of neotropical ant assemblages. Oecologia 116, 191-201. 
571 Frazer, G.W., Trofymow, J.A., Lertzman, K.P., 1997. A method for estimating canopy openness, effective leaf area index, and photosynthetically active photon flux density using hemispherical photography and computerized image analysis techniques. Canadian Forest Service, Pacific Forestry Center, Victoria.

Gallet, C., 1992. Apports de la biochimie à la connaissance du fonctionnement des écosystèmes forestiers: rôle des composés phénoliques dans une pessière à myrtille. Université Claude-Bernard-Lyon I, Ph. D.

Gaston, K.J., 2000. Global patterns in biodiversity. Nature 405, 220-227.

Grgič, T., Kos, I., 2005. Influence of forest development phase on centipede diversity in managed beech forests in Slovenia. Biodiversity and Conservation 14, 1841-1862.

581 Grossi, J.L., Brun, J.-J., 1997. Effect of climate and plant succession on lumbricid populations in the French Alps. Soil Biology and Biochemistry 29, 329-333.

Hågvar, S., 1982. Collembola in Norwegian coniferous forest soils. I. Relations to plant communities and soil fertility. Pedobiologia 24, 255-296.

Hågvar, S., Kjøndal, R.B., 1981. Succession, diversity and feeding habits of microarthropods in decomposing birch leaves. Pedobiologia 22, 385-408.

Hasegawa, M., Takeda, H., 1996. Carbon and nutrient dynamics in decomposing needle litter in relation to fungal abundances. Pedobiologia 40, 171-184.

Huhta, V., Mikkonen, M., 1982. Population structure of Entomobryidae (Collembola). In a mature spruce stand and in clear-cut reforested areas in Finland. Pedobiologia 24, 231240.

Imbeck, H., Ott, E., 1987. Verjüngungsökologische Untersuchungen in einem hochstaudenreichen subalpinen Fichtenwald, mit spezieller Berücksichtigung der Schneeablagerung und der Lawinenbildung. Mitt. EISLF, Switzerland, 202 pp. 
Kaspari, M., Yuan, M., Alonso, L., 2003. Spatial grain and the causes of regional diversity gradients in ants. The American Naturalist 161, 459-477.

Krom, M.D., 1980. Spectrophotometric determination of ammonia : A study of a modified Berthelot reaction using salicylate and dichloroisocyanurate. Analyst 105, 305-316.

Kuznetsova, N.A., 2002. Classification of collembolan communities in the east-european 600 taiga: Proceedings of the Xth international Colloquium on Apterygota, České Budějovice 2000: Apterygota at the Beginning of the Third Millennium. Pedobiologia 46, 373-384.

Lawrence, K.L., Wise, D.H., 2000. Spider predation on forest-floor Collembola and evidence for indirect effects on decomposition. Pedobiologia 44, 33-39.

Loranger, G., Bandyopadhyaya, I., Razaka, B., Ponge, J.-F., 2001. Does soil acidity explain altitudinal sequences in collembolan communities? Soil Biology and Biochemistry 33, 381-393.

Magura, T., Tóthmérész, B., Elek, Z., 2003. Diversity and composition of carabids during a forestry cycle. Biodiversity and Conservation 12, 73-85.

Materna, J., 2004. Does forest type and vegetation patchiness influence horizontal distribution of soil Collembola in two neighbouring forest sites? Pedobiologia 48, 339-347.

Migge, S., Maraun, M., Scheu, S., Schaefer, M., 1998. The oribatid mite community 616 Neumann, H.H., Den Hartog, G.D., Shaw, R.H., 1989. Leaf-area measurements based on 617 hemispheric photographs and leaf-litter collection in a deciduous forest during autumn leaf-fall. Agricultural and Forest Meteorology 45, 325-345. 
619 O'Connor, F.B., 1957. An ecological study of the enchytreid worm population of a coniferous forest soil. Oikos 8, 161-169.

621 Paquin, P., Coderre, D., 1997. Changes in soil macroarthropod communities in relation to forest maturation through three successional stages in the Canadian boreal forest. Oecologia 112, 104-111.

Parmelee, R.W. 1995. Soil fauna: linking different levels of the ecological hierarchy. In: Jones, C.G., Lawton, J. (eds.), Linking species and ecosystems. Chapman and Hall, New York, pp. 107-116.

Peltier, A., Ponge, J.-F., Jordana, R., Ariño, A., 2001. Humus forms in Mediterranean scrublands with Aleppo Pine. Soil Science Society of America Journal 65, 884-896.

Ponge, J.-F., 1985. Utilisation de la Micromorphologie pour l'étude des relations trophiques dans le sol: la couche L d'un moder hydromorphe sous Pinus sylvestris (Forêt d'Orléans, France). Bulletin d'Ecologie - Ecologie 16, 117-132.

Ponge, J.-F., 1991. Succession of fungi and fauna during decomposition of needles in a small area of Scots pine litter. Plant and Soil 138, 99-113.

Ponge, J.-F., 1993. Biocenoses of Collembola in atlantic temperate grass-woodland ecosystems. Pedobiologia 37, 223-244.

Ponge, J.-F., 2000. Biodiversité et biomasse de la faune du sol sous climat tempéré. Comptes rendus de l'Académie d'agriculture de France 8, 129-135.

Ponge, J.-F., 2003. Humus forms in terrestrial ecosystems: a framework to diversity. Soil Biology and Biochemistry 35, 935-945.

Ponge, J.-F., Chevalier, R., Loussot, P., 2002. Humus index: an integrated tool for the Journal 66, 1996-2001. 
643 Salmon, S., Ponge, J.-F., 1998. Response to light in a soil-dwelling springtail. European Journal of Soil Biology 34, 199-201.

645 Salmon, S., Ponge, J.F., 1999. Distribution of Heteromurus nitidus (Hexapoda, Collembola) 646 according to soil acidity: interactions with earthworms and predator pressure. Soil Biology and Biochemistry 31, 1161-1170.

Salmon, S., Geoffroy, J.-J., Ponge, J.-F., 2005. Earthworms and collembola relationships: effect of predatory centipedes and humus forms. Soil Biology and Biochemistry 37, $487-415$.

Salmon, S., Mantel, J., Frizzera, L., Zanella, A., 2006. Changes in humus forms and soil animal communities in two developmental phases of Norway spruce on an acidic substrate. Forest Ecology and Management 237, 47-56.

Salmon S., Frizzera L., Camaret S,. submitted. Linking forest dynamics to biodiversity and soil functioning.

Schaefer, M., Schauermann, J., 1990. The soil fauna of beech forests: comparison between a mull and a moder soil. Pedobiologia 34, 299-314.

Scheu, S., Albers, D., Alphei, J., Buryn, R., Klages, U., Migge, S., Platner, C., Salamon, J.-A., 2003. The soil fauna community in pure and mixed stands of beech and spruce of different age: trophic structure and structuring forces. Oikos 101, 225-238.

Scheu, S., Falca, H., 2000. The soil food web of two beech forests (Fagus sylvatica) of contrasting humus types: stable isotope analysis of a macro-and a mesofauna-dominated system. Oecologia 123, 285-295.

Schwartz, M. W., Brigham, C.A., Hoeksema, J.D., Lyons, K.G., Mills, M.H., van Mantgem, 666 P.J., 2000. Linking biodiversity to ecosystem function: implications for conservation ecology. Oecologia 122, 297-305. 
Setälä, H., Tyynismaa, M., Martikainen, E., Huhta, V., 1991. Mineralization of C, N and P in relation to decomposer community structure in a coniferous forest soil. Pedobiologia 35, 285-296.

Sokal, R.R., Rohlf., F.J., 1995. Biometry. 3rd edition. W.H. Freeman and Company, New York, $887 \mathrm{pp}$.

Sømme, L., 1993. Living in the cold. Biologist 40, 14-17.

Srivastava, D.S., Lawton, J.H., 1998. Why more productive sites have more species: an experimental test of theory using tree-hole communities. The American Naturalist 152, 510-529.

Toutain, F., 1987. Activité biologique des sols, modalités et lithodépendance. Biology and Fertility of Soils 3, 31-38.

Vedder, B., Kampichler, C., Bachmann, G., Bruckner, A., Kandeler, E., 1996. Impact of faunal complexity on microbial biomass and $\mathrm{N}$ turnover in field mesocosms from a spruce forest soil. Biology and Fertility of Soils 22, 22-30.

Verhoef, H.A., Brussaard, L., 1990. Decomposition and nitrogen mineralization in natural and agro-ecosystems: the contribution of soil animals. Biogeochemistry 11, 175-211.

Wardle, D.A., 2002. Communities and ecosystems. Linking the aboveground and belowground components. Princeton University Press.

Wright, D.H., 1983. Species-energy theory: an extension of species-area theory. Oikos 41, 496-506.

Zaitsev, A.S., Chauvat, M., Pflug, A., Wolters, V., 2002. Oribatid mite diversity and community dynamics in a spruce chronosequence. Soil Biology and Biochemistry 34, 1919-1927. 


\section{Legends}

692

693 Fig. 1. Correspondence analysis. Projection along Axes 1 and 2 of zoological taxa (active 694 variables), and the following passive variables: exposure (EXPS, EXPN), tree stands (mature, 695 regeneration, clearing), sampling areas $(\mathrm{CN}, \mathrm{RN}, \mathrm{MN}$ : clearing, regeneration and mature in 696 the north-facing site, and CS, RS, MS: clearing, regeneration and mature in the south-facing 697 site) and descriptors of soil fauna communities (H', predators, zoological richness, 698 abundance). See codes of zoological taxa in Table 1. Bordered and underlined names are 699 significantly correlated to Axis 1 and 2, respectively.

701 Fig. 2. Correspondence analysis. Projection along Axes 1 and 2 of environmental 702 characteristics (passive variables), exposure (south-facing: EXPS, north-facing: EXPN), tree 703 developmental phase (clearing, regeneration, mature), and sampling areas (CN, RN, MN: 704 clearing, regeneration and mature in the north-facing site, and CS, RS, MS: clearing, 705 regeneration and mature in the south-facing site). See codes used for environmental variables 706 in Table 1. Bordered and underlined names are significantly correlated to Axis 1 and 2, 707 respectively. 
711 Table 1. Density of zoological groups, predators, and total fauna (mean per $\mathrm{m}^{2}$ ), in three 712 developmental phases of spruce: regeneration $(\mathrm{R})$, mature $(\mathrm{M})$ and clearing $(\mathrm{C})$, in north713 facing and south-facing sites. Different letters inside the lines "predators" and "total 714 abundance" indicate a significant difference $(\mathrm{p}<0.05)$ between the six stands. Codes 715 correspond with those used in the correspondence analysis graphs (Figs. 1 and 2).

716 Entomobryom.= Entomobryomorpha. 


\begin{tabular}{|c|c|c|c|c|c|c|c|}
\hline & & \multicolumn{3}{|c|}{ North } & \multicolumn{3}{|c|}{ South } \\
\hline Zoological taxa & Code & $\mathbf{C}$ & $\mathbf{R}$ & $\mathbf{M}$ & $\mathbf{C}$ & $\mathbf{R}$ & $\mathbf{M}$ \\
\hline Acari & MITES & 66645.4 & 61047.3 & 131873.6 & 81207.5 & 155612.2 & 261576.9 \\
\hline Oribatida & ORIBT & 43154.8 & 49036.3 & 83120.7 & 56831.1 & 112705.5 & 176338.0 \\
\hline Actinedida & ACT & 283.4 & 283.4 & 0.0 & 0.0 & 141.7 & 0.0 \\
\hline Acaridida & ACAR & 141.7 & 106.3 & 2019.6 & 389.7 & 141.7 & 491.8 \\
\hline Gamasina & GAM & 4464.3 & 1984.1 & 3011.6 & 3365.9 & 6519.3 & 7007.6 \\
\hline Uropodina & URO & 3862.0 & 5350.1 & 2948.8 & 5527.2 & 5846.1 & 5163.5 \\
\hline Acari larvae & L.ACA & 14739.2 & 4074.5 & 40320.3 & 14455.8 & 30257.9 & 72676.0 \\
\hline Collembola & COLL & 33340.4 & 37131.5 & 22959.2 & 42594.2 & 63740.1 & 13236.6 \\
\hline Entomobryom. & C.ENT & 18388.6 & 20797.9 & 15058.1 & 19061.8 & 44997.2 & 5327.4 \\
\hline Poduromorpha & C.POD & 7405.0 & 15270.7 & 7865.6 & 24270.1 & 21293.9 & 7868.2 \\
\hline Symphypleona & C.SYMP & 425.2 & 921.2 & 0.0 & 177.2 & 0.0 & 40.9 \\
\hline Neelipleona & C.NEEL & 7121.6 & 566.9 & 35.4 & 318.9 & 992.1 & 0.0 \\
\hline Aranea & ARAI & 70.9 & 177.2 & 70.9 & 70.9 & 212.6 & 41.0 \\
\hline Protura & PROT & 1665.2 & 992.1 & 1098.4 & 3047.1 & 5456.3 & 1147.4 \\
\hline Thysanoptera & THYS & 0.0 & 0.0 & 0.0 & 35.9 & 0.0 & 204.9 \\
\hline $\begin{array}{l}\text { Coleoptera } \\
\text { adult }\end{array}$ & $\mathrm{COL}$ & 70.9 & 318.9 & 106.3 & 141.7 & 425.2 & 122.9 \\
\hline $\begin{array}{l}\text { Coleoptera } \\
\text { larvae }\end{array}$ & L.COL & 318.9 & 70.9 & 354.3 & 118.9 & 425.2 & 1147.4 \\
\hline Homoptera & HOM & 248.0 & 212.6 & 177.2 & 354.3 & 141.7 & 204.9 \\
\hline Diptera larvae & L.DIP & 0.0 & 850.3 & 354.3 & 177.2 & 389.7 & 573.7 \\
\hline Chilopoda & CHIL & 106.3 & 0.0 & 35.4 & 0.0 & 318.9 & 0.0 \\
\hline Diplopoda & DIP & 0.0 & 35.4 & 0.0 & 35.4 & 35.4 & 0.0 \\
\hline Symphyla & SYMPH & 283.4 & 35.4 & 70.9 & 35.4 & 283.4 & 0.0 \\
\hline Enchytraeidae & ENC & 5881.5 & 7901.1 & 3259.6 & 5172.9 & 3862.0 & 5491.3 \\
\hline Predators & & 5031.2 & 2586.5 & 3224.2 & 3507.7 & 7263.3 & 7130.6 \\
\hline Total abundance & & $109835.6^{\mathbf{c}}$ & $108737.2^{c}$ & $160360.0^{\mathbf{a b c}}$ & $133290.8^{\mathbf{b c}}$ & $230902^{\mathbf{a}}$ & $283747.2^{\mathbf{a b}}$ \\
\hline
\end{tabular}


719 Table 2. Zoological richness, Shannon-Wiener index and the composition of invertebrate 720 communities expressed as coordinates of axes 1 and 2 of CA, in three developmental phases

721 of spruce: regeneration (R), mature (M) and clearing (C), in north-facing and south-facing 722 sites. Different letters inside a line indicate a significant difference $(p<0.05)$ between the six 723 stands or the two exposures.

\begin{tabular}{|c|c|c|c|c|c|c|}
\hline & \multicolumn{3}{|c|}{ North } & \multicolumn{3}{|c|}{ South } \\
\hline & $\mathrm{C}$ & $\mathbf{R}$ & $\mathbf{M}$ & $\mathbf{C}$ & $\mathbf{R}$ & $\mathbf{M}$ \\
\hline Shannon index & $\begin{array}{l}0.39^{\mathbf{a}} \\
(0.06)\end{array}$ & $\begin{array}{l}0.40^{\mathbf{a}} \\
(0.06)\end{array}$ & $\begin{array}{l}0.22^{\mathbf{b}} \\
(0.04)\end{array}$ & $\begin{array}{l}0.37^{\mathrm{a}} \\
(0.04)\end{array}$ & $\begin{array}{l}0.35^{\mathrm{a}} \\
(0.03)\end{array}$ & $\begin{array}{l}0.16^{\mathbf{b}} \\
(0.03)\end{array}$ \\
\hline $\begin{array}{l}\text { Zoological } \\
\text { richness }\end{array}$ & $\begin{array}{l}5.8 \\
(0.7)\end{array}$ & $\begin{array}{c}5.4 \\
(0.8)\end{array}$ & $\begin{array}{l}5.1 \\
(0.9)\end{array}$ & $\begin{array}{l}5.9 \\
(0.5)\end{array}$ & $\begin{array}{l}6.9 \\
(0.6)\end{array}$ & $\begin{array}{l}5.3 \\
(0.8)\end{array}$ \\
\hline $\begin{array}{l}\text { Coordinates of } \\
\text { axis } 1 \text { of CA } \\
(\mathrm{p}=0.08)\end{array}$ & $\begin{array}{l}-0.002^{\mathrm{a}} \\
(0.011)\end{array}$ & $\begin{array}{l}-0.005^{\mathrm{a}} \\
(0.009)\end{array}$ & $\begin{array}{l}-0.010^{\mathrm{a}} \\
(0.006)\end{array}$ & $\begin{array}{l}-0.004^{\mathrm{a}} \\
(0.005)\end{array}$ & $\begin{array}{c}0.02^{\mathrm{b}} \\
(0.006)\end{array}$ & $\begin{array}{c}-0.001^{\mathrm{ab}} \\
(0.007)\end{array}$ \\
\hline $\begin{array}{l}\text { Coordinates of } \\
\text { axis } 2 \text { of CA }\end{array}$ & $\begin{array}{l}-0.008^{\mathbf{a}} \\
(0.003)\end{array}$ & $\begin{array}{l}-0.009^{\mathbf{a}} \\
(0.003)\end{array}$ & $\begin{array}{l}0.005^{\mathbf{b c}} \\
(0.007)\end{array}$ & $\begin{array}{c}-0.005^{\mathbf{a b}} \\
(0.002)\end{array}$ & $\begin{array}{c}-0.007^{\mathbf{a b}} \\
(0.002)\end{array}$ & $\begin{array}{l}0.028^{c} \\
(0.004)\end{array}$ \\
\hline $\begin{array}{l}\text { Coordinates of } \\
\text { axis } 1 \text { of } C A\end{array}$ & \multicolumn{3}{|c|}{$-0.006(0.004)^{\mathbf{a}}$} & \multicolumn{3}{|c|}{$0.006(0.005)^{\mathbf{b}}$} \\
\hline
\end{tabular}


Table 3. Mean density and standard error of the physical-chemical soil and leachate

737 parameters in stands of three developmental phases of spruce: regeneration (R), mature (M)

738 and clearing (C), in north-facing and south-facing sites. Different letters inside a line indicate

739 a significant difference $(\mathrm{p}<0.05)$ between the six stands. Codes correspond with those used in

740 the correspondence analysis graphs (Figs. 1 and 2).

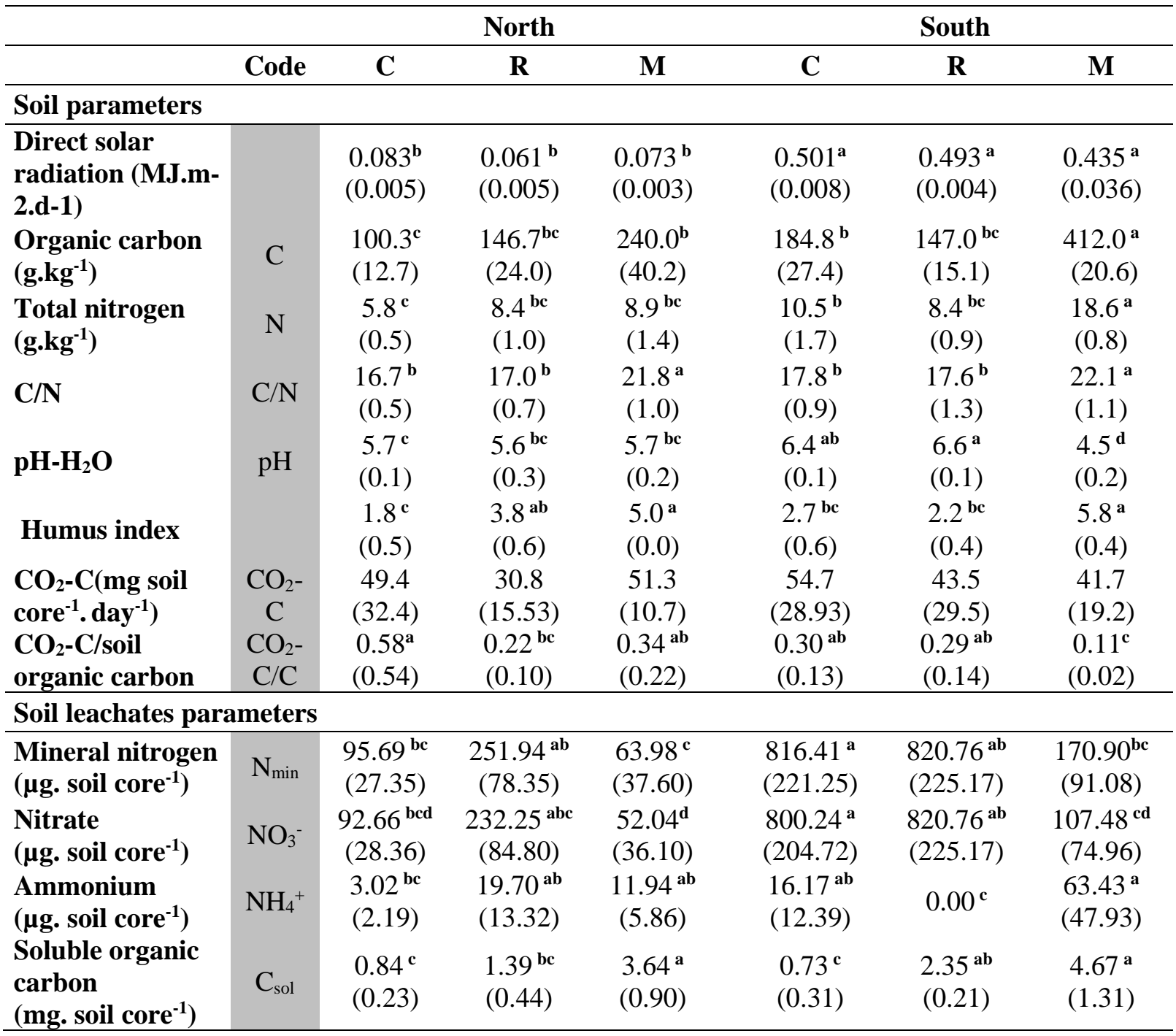


2 Fig. 1

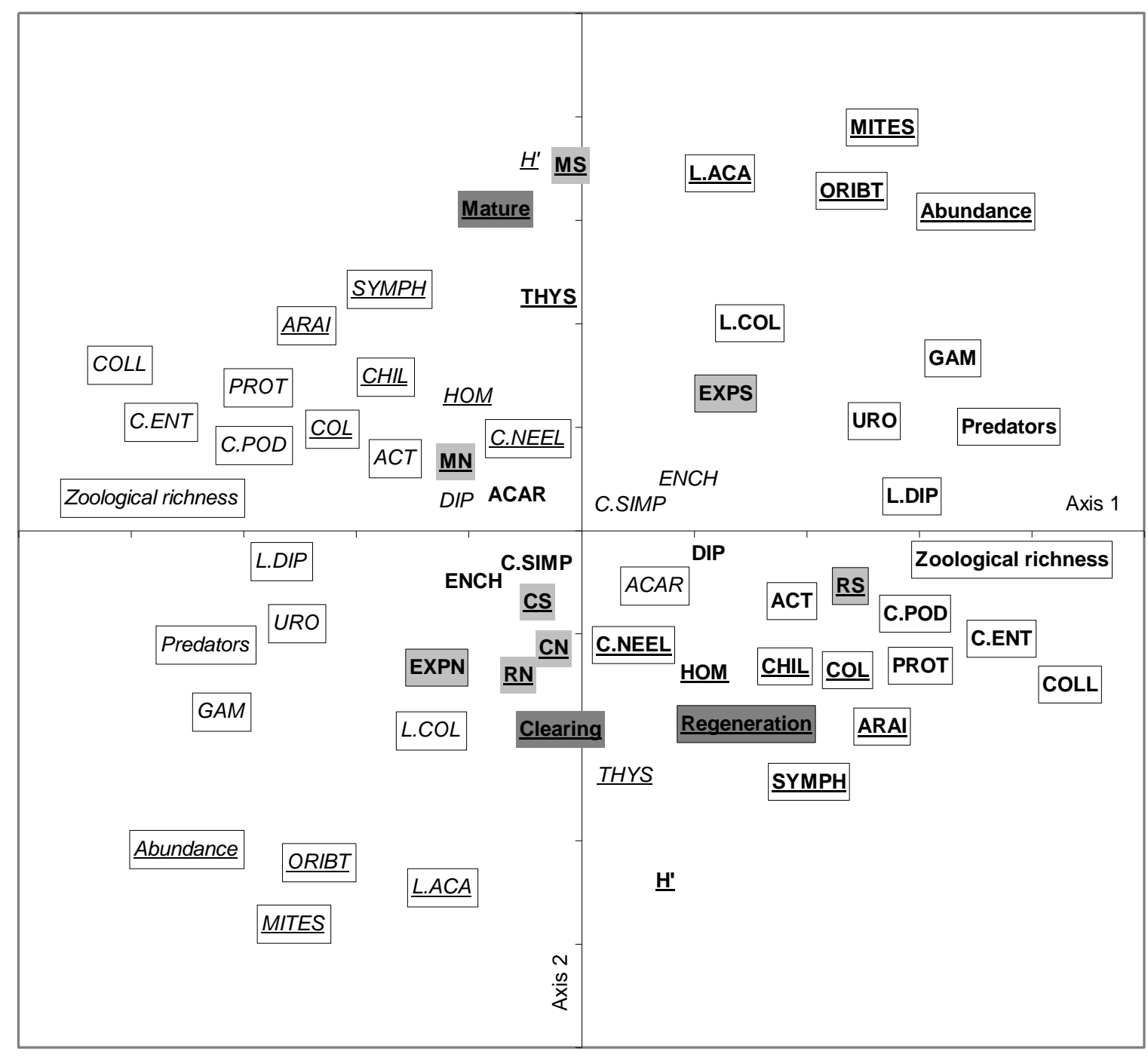

3

4 
1 Fig. 2

2

3

4

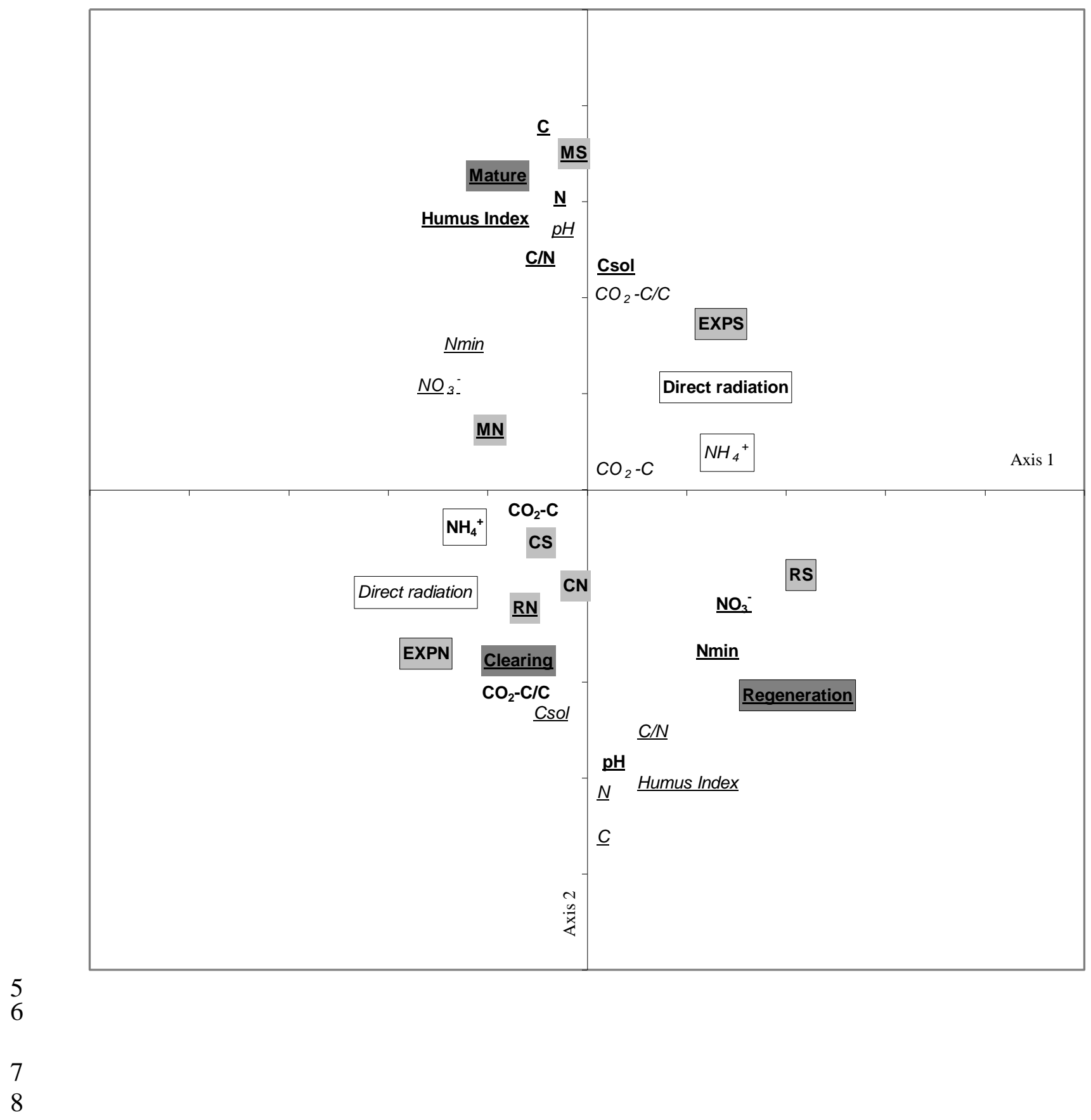

